\title{
The Development of Digital Economy in Indonesia
}

Artikel yang berjudul "The Development of Digital Economy in Indonesia" yang disusun oleh Ahmad Zafurllah Tayibnapis, Lucia E. Wuryaningsih, dan Raditya Gora ini bertemakan kemajuan tekonologi internet di dunia yang berdampak pada bidang industri di Indonesia.

Pada artikel ini memberikan suatu fakta mengenai perkembangan teknologi internet di dunia. Fakta tersebut dibuktikan dimana kenaikan jumlah pengguna internet mencapai 50\% dari total masyarakat. Perkembangan tekonologi internet tersebut semakin memudahkan manusia dalam melakukan aktifitasnya. Hanya bermodalkan teknologi dan internet, manusia dapat melakukan pekerjaannya. Salah satu contohnya yaitu sebanyak 6.5 juta pengguna internet merupakan pengguna belanja online per tahun.

Teknologi akan semakin berkembang dan akan semakin memudahkan manusia dalam melakukan segala aktifitasnya. Hal tersebut semakin nyata dimana saat ini dunia telah memasuki Era Industri 4.0 yang mampu mengubah seluruh rantai dan manejemen di berbagai industri. Salah satunya yaitu layanan keuangan berbasis teknologi yang berkembang pesat di Indonesia seperti internet banking, mobile banking, AMS banking, ATM, e-money,dll. Hal tersebut menunjukkan bahwa teknologi mampu memberikan akses layanan keuangan menjadi lebih praktis.

Kedua pernyataan tersebut merupakan suatu fakta yang tidak hanya berdasarkan hasil survey tetapi juga kami merasakan dimana kami semakin dimudahkan dalam melakukan pemblian suatu barang dengan cara online dan dalam melakukan pembayaran yang saat ini sangat jarang menggunakan uang cash serta dalam melakukan transfer antar bank hanya dapat dilakukan tanpa harus hadir ke bank.

Berdasarkan temuan diartikel tersebut dikatakan bahwa digital technology berkembang begitu pesat diseluruh dunia, namun tidak banyak negara yang memperhatikan atau memikirkan manfaat yang dapat muncul ketika sebuah negara mulai mengembangkan digital technologynya. Indonesia, merupakan salah satu negara yang kurang memperhatikan perkembangan digital technology. Hal tersebut diperkuat ketika masuknya Go-Jek, Grab,dan Uber yang merupakan transportasi online mendapat penolakan keras dari berbagai pihak terutama pihak driver kendaraan konvensional. Mungkin memang ada beberapa dampak yang negatif jika digital technology masuk ke suatu negara tanpa sebuah kesiapan dari Sumber Daya Manusia nya sehingga menyebabkan banyaknya penolakan dari berbagai pihak. Namun 
ketika kita melihat dimasa sekarang ini, kita dapat melihat begitu mudahnya kehidupan sehari-hari kita ketika menggunakan digital technology, mulai dari mencari kendaraan umum, makanan, bahkan pembayaran yang sekarang ini menggunakan cash less/ transaksi berbasis digital. Selain itu, dengan adanya bank berbasis online atau digital technology ini dapat meminimalisir kesalahan yang dapat terjadi karena adanya human error, dan juga dengan adanya bank berbasis digital technology dapat memudahkan semua orang dalam bertransaksi dimanapun dan kapanpun.

Jika dilihat dari sisi ekonomi makronya, digital technology saat ini sangat berpengaruh dalam perekonomian suatu negara dimana dengan adanya digital technology maka pengangguran disuatu negara terutama Indonesia dapat berkurang. Hal ini disebabkan karena dengan adanya Digital Technology, semua orang dapat membuka bisnisnya secara online tanpa perlu membayar biaya sewa toko dan dapat menjadi bos atau seorang entrepreneur bagi dirinya sendiri. Maka dari itu, suatu negara seharusnya lebih memperhatikan pada perubahan jaman yang begitu cepat terutama era digital ini, karena jika suatu negara mempunyai kesiapan dalam menghadapi perubahan-perubahan yang ada, maka suatu negara dapat menggunakan peluang tersebut dalam mensejahterakan warga negaranya serta dapat meningkatkan perekonomian negara tersebut serta meminimalisir penggangguran yang ada.

Kelompok 9 :

Nico Abertnego/ KP D/ 130318146

Richard Agung / KP D/ 130318148

Cindy Alexanra/ KP D/ 130318150

Johanna Beriana/ KP D/ 130318161 